\title{
Relationship of spruce budworm (Choristoneura fumiferana) emer- gence and balsam fir (Abies balsamea) bud flush to climate indices
}

\author{
by Alan J. Thomson ${ }^{1}$
}

\begin{abstract}
Temperature records from weather stations across eastern Canada were used with published data on degree-day requirements for spruce budworm larval emergence and balsam fir bud flush to estimate historical patterns of larval emergence and timing of bud flush. The pattern of association was studied using Response Surface Analysis and was found to vary from west to east. April values of the Pacific/North American (PNA) pattern, Pacific Decadal Oscillation (PDO) and Northern Annular Mode (NAM) climate indices showed the most significant relationship to both emergence and bud flush in the 2 Ontario stations, while May values of the PDO and Eastern Pacific (EP) indices were most significant in the 4 Quebec and New Brunswick locations.
\end{abstract}

Key words: phenology, balsam fir, teleconnections

\section{RÉSUMÉ}

Les températures relevées dans les stations météorologiques de l’est du Canada ont été utilisées avec les données publiées de degrés-jours requis pour l'émergence des larves de tordeuses des bourgeons de lépinette et le débourrement des bourgeons du sapin baumier afin d'estimer les patrons historiques démergence larvaires et le moment du débourrement des bourgeons. Le mode d'association a été étudié au moyen de l'Analyse localisée des surfaces et a démontré une variation douest en est. La valeur des indices climatiques du mois d’avril du patron nord-américain du Pacifique, de loscillation décennale du Pacifique et de loscillation nord-atlantique ont révélé une relation très significative entre lémergence et le débourrement des bourgeons pour les deux stations de l'Ontario, tandis que les valeurs du mois de mai de l'ODC et du Pacifique oriental (PO) étaient le plus significatives pour les quatre emplacements du Québec et du Nouveau-Brunswick.

Mots clés : phénologie, sapin baumier, relations directes

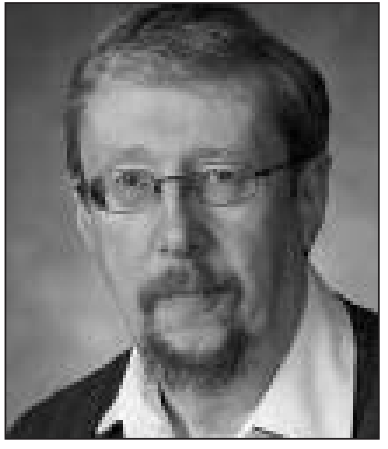

Alan J. Thomson

\section{Introduction}

"Large-scale climatic indices such as the North Atlantic Oscillation are associated with population dynamics, variation in demographic rates and values of phenotypic traits in many species" (Hallett et al. 2004), and these large-scale indices often outperform local weather variables when it comes to explaining climaterelated variation in life history traits or animal numbers (Stenseth and Mysterud 2005). Coupled interactions between the atmosphere and ocean can lead to large systematic seasonal or annual fluctuations of climate on time scales from seasons, and year to year (Salinger et al. 2000). At the global scale, the El Niño - Southern Oscillation (ENSO) is the most important source of this variability (Allan et al. 1996), while the North Atlantic Oscillation (NAO) modulates European climate (Hurrell 1995). Variations in ENSO and NAO have been associated with anomalies in temperature and precipita- tion related to extreme events including droughts and wildfires (Kitzberger et al. 2001, Pereira et al. 2005, Brolley et al. 2007), Canadian wheat yields (Hsieh et al. 1999), and herbivore species outbreaks (Van Bael et al. 2004).

Zhou et al. (2001) demonstrate that for the continental United States, seasonal (3-month) temperature and precipitation anomalies are related to combinations of climate indices, ENSO and NAM (Northern Annular Mode) in that study, rather than to a single index. In a more detailed study in a Canadian setting, Thomson (2009) used Response Surface Analysis to show that mountain pine beetle-killing temperatures across western Canada was related to NAM in combination with the Pacific/North American Pattern (PNA), rather than with ENSO.

The importance of climate and weather to budworm cycles was reviewed by Blais (1985), who indicated that several outbreaks had been preceded by summer drought. In the western spruce budworm, synchronization of larval emergence and host bud flush is important for western budworm (C. occidentalis Freeman) survival and outbreak cycles (Thomson et al. 1984, Thomson and Benton 2007), and synchronization is similarly important for other insect species (van Asch and Visser 2007).

\footnotetext{
${ }^{1}$ Formerly with Natural Resources Canada, Canadian Forest Service, Pacific Forestry Centre, 506 West Burnside Road, Victoria, British Columbia V8Z 1M5. Current E-mail: ajthomson@shaw.ca
} 
Degree days (DDs) calculated from historical weather records (Thomson et al. 1984, Thomson and Benton 2007) or predicted records (Jönsson et al. 2007) can be used to estimate insect and bud development and their synchronization. In the present study, Response Surface Analysis is used to evaluate the relationship of estimates of spruce budworm emergence and balsam fir bud flush based on degree days in eastern Canada to climate index combinations.

\section{Methods}

Budworm and balsam fir development

Cameron et al. (1968) indicate that $81 \mathrm{DD}$ above $2.78^{\circ} \mathrm{C}$ starting April 1 are required for emergence of the second instar larvae in spring. Balsam fir (Abies balsamea [L.] Mill.) is the principal host of spruce budworm. Bud development stage 1 of Osawa et al. (1983) was used for estimating synchronization with larval emergence, with $120 \mathrm{DD}$ above $4^{\circ} \mathrm{C}$ starting April 1 being required to reach stage 1 .

In determining bud flush, a single combination of DD total, starting date for accumulation, and threshold temperature is used for bud development across the entire $2400 \mathrm{~km}$ range of the study. In addition, no photoperiod is used in determining start date of bud development, with accumulation beginning on April 1, the same as for the larvae. The bud development data (Osawa et al. 1983) on which estimates are based, were obtained from a location $170 \mathrm{~km}$ from Aroostook and 870 $\mathrm{km}$ from Cochrane, for which it will be much less representative. Bud development is under tight genetic control, for example to avoid damage by late frosts. The last day within a year with temperature below $0^{\circ} \mathrm{C}$ was used as an indicator of late frost occurrence at each location.

\section{Data sources: temperature and precipitation}

Daily minimum and maximum temperature records were obtained from the Environment Canada dataset (http:// www.climate.weatheroffice.ec.gc.ca/prod_servs/cdcd_iso_e.h $\mathrm{tml})$. As some of the climate indices are only available since 1950, only years of weather between 1950 and 2000 are considered in the evaluation of all climate indices. Six weather stations, 2 each from Ontario (ON), Quebec (QC) and New Brunswick (NB) were included in the study (Table 1). Missing data were estimated from preceding days (Kemp et al. 1983). Years in which the entire month of data was missing were omitted from the analyses.

\section{Data sources: climate indices}

Climate index data ${ }^{2}$ were downloaded from Internet sites (Table 2). Some indices, such as ENSO, are based on sea surface temperatures while others, such as PNA, are based on atmospheric pressure. Some pressure-based indices are only available from 1950. Note that for some indices, such as the $\mathrm{NAO}$, there may be different approaches to determining the index (Hurrell et al. $2003^{3}$ ). In such cases, only the approach

\footnotetext{
${ }^{2}$ for more information on climate indices see http://www.cdc. noaa.gov/enso/enso.glossary.html [Accessed August 18, 2008]

${ }^{3}$ see also http://www.cgd.ucar.edu/cas/jhurrell/indices.html [Accessed August 18, 2008]
}

Table 1. Weather stations included in the study, in order from west to east. Station abbreviations are CF: Cameron Falls; Coc: Cochrane; Lat: La Tuque; Aro: Aroostook; Cau: Causapscal; Mon: Moncton.

\begin{tabular}{lcccc}
\hline Station & ID & Lat. & Long. & $\begin{array}{c}\text { Elevation } \\
(\mathbf{m})\end{array}$ \\
\hline CF (ON) & 6041109 & $49^{\circ} 09^{\prime} \mathrm{N}$ & $88^{\circ} 21^{\prime} \mathrm{W}$ & 229 \\
Coc (ON) & 6071712 & $49^{\circ} 04^{\prime} \mathrm{N}$ & $81^{\circ} 3^{\prime} \mathrm{W}$ & 275 \\
LaT (QC) & 7074240 & $47^{\circ} 24^{\prime} \mathrm{N}$ & $72^{\circ} 46^{\prime} \mathrm{W}$ & 152 \\
Aro (NB) & 8100300 & $46^{\circ} 48^{\prime} \mathrm{N}$ & $67^{\circ} 43^{\prime} \mathrm{W}$ & 91 \\
Cau (QC) & 7051200 & $48^{\circ} 22^{\prime} \mathrm{N}$ & $67^{\circ} 14^{\prime} \mathrm{W}$ & 168 \\
Mon (NB) & 8103100 & $46^{\circ} 06^{\prime} \mathrm{N}$ & $64^{\circ} 36^{\prime} \mathrm{W}$ & 12 \\
\hline
\end{tabular}

in Table 2 was included. Response surfaces of budworm emergence date and bud flush date were analyzed at each station of Table 1 using April values of all pair-wise combinations of the indices in Table 2, and repeated with May values of all pair-wise combinations of the indices.
Table 2. Sources of climate index data used in the analyses. ENSO: El Niño-Southern Oscillation; EP: East Pacific; NAM: Northern Annular Mode; NAO: North Atlantic Oscillation; NPI: North Pacific Index; Northern Oscillation Index; PDO:

\begin{tabular}{|c|c|}
\hline Index & Source \\
\hline ENSO: & http://www.iphc.washington.edu/Staff/hare/html/decadal/post1977/nino34.txt \\
\hline EP & $\mathrm{ftp}: / / \mathrm{ftp} . c p c . n c e p . n o a a . g o v / w d 52 \mathrm{dg} / \mathrm{data} /$ indices/tele_index.nh \\
\hline NAM & http://159.226.113.17/staff/ljp/data-NAM-SAM-NAŌNAM-AO.htm \\
\hline $\mathrm{NAO}$ & http://www.cgd.ucar.edu/cas/jhurrell/indices.data.html \\
\hline NOI & http://www.cdc.noaa.gov/Correlation/noi.data \\
\hline NPI & http://www.cdc.noaa.gov/Pressure/Timeseries/Data/np.long.data \\
\hline $\mathrm{PDO}$ & ftp://ftp.atmos.washington.edu/mantua/pnw_impacts/INDICES/PDO.latest \\
\hline PNA & ftp://ftp.cpc.ncep.noaa.gov/wd52dg/data/indices/tele_index.nh \\
\hline
\end{tabular}

\section{Statistical analyses}

Response surface methodology can be used to explore a response over a region of factor space and is based on least squares fitting (Vidmar and McKean 1996). Response Surface Analysis of the data was performed using Minitab ${ }^{\circledast}$ Release 15 (Minitab Inc.) (Thomson 2009). In Fig. 1 and Fig. 2, the data point distributions, in which symbol size was scaled relative to the emergence or bud flush data, were created in SigmaPlot 9.0 (Systat Software Inc.). The SigmaPlot graphs were then scaled to the Minitab graph size and overlaid on the response surfaces. The density of the scaled data points in the figures indicates the frequency with which particular combinations of index level occur, and the consequent likelihood of particular values of emergence or bud flush. The distribution of different-sized points helps illustrate the fit of the trend to the data in different regions of the graphs. Combinations of indices with graphical evidence of overfitting, such as saddle points in the response surface, were excluded.

\section{Results}

Year-to-year variability in larval emergence and bud flush

Estimated dates of larval emergence and bud flush were evaluated for all pair-wise combinations of the indices in Table 2. The combinations of indices with the highest $r^{2}$ values are shown (Table 3 ). 

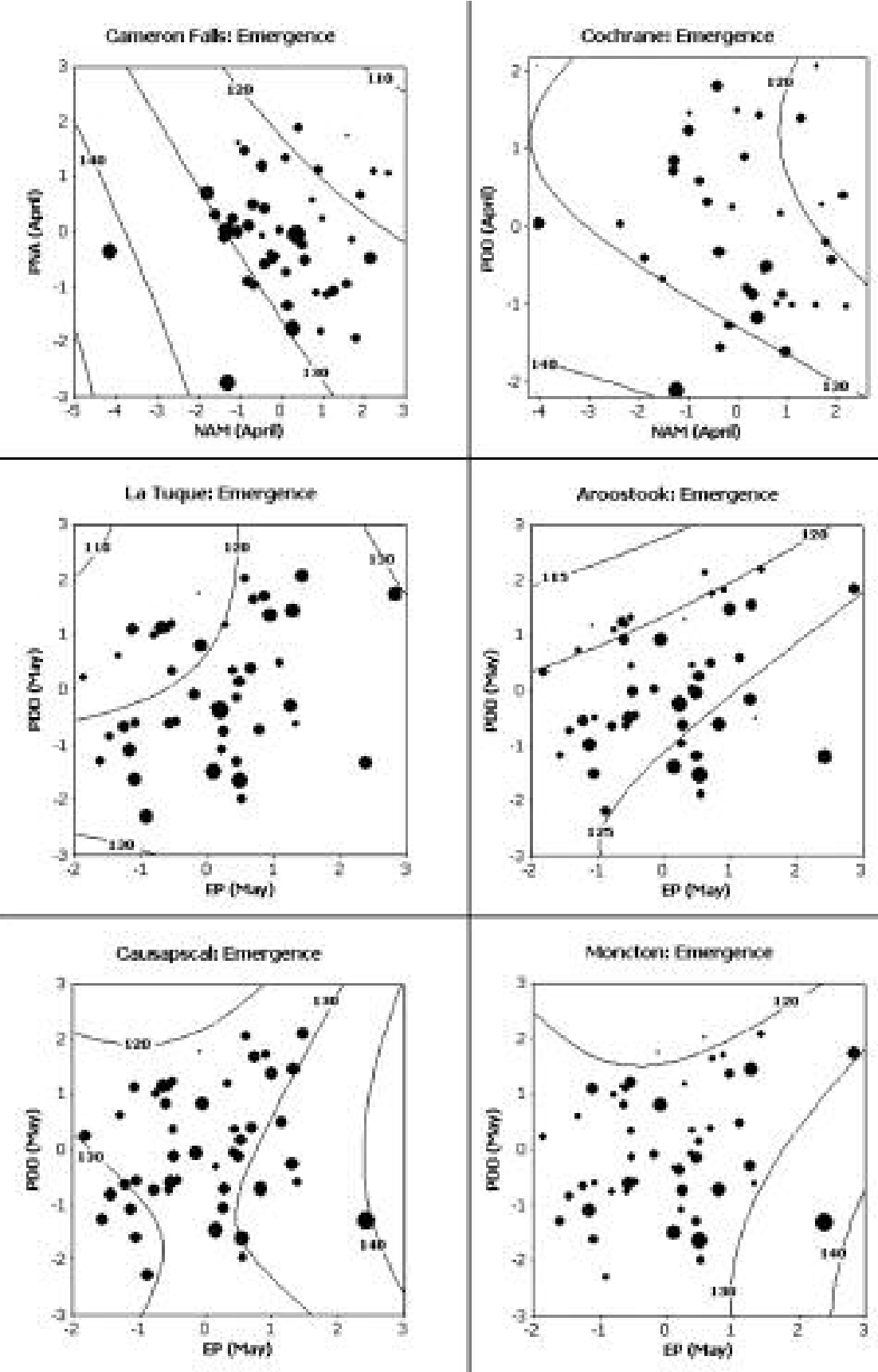

Fig. 1. Relationship of climate indices to day of emergence for the stations in the study, in order from west to east. $r^{2}$ values are listed in Table 3. Point size is scaled between the smallest at the minimum and maximum predicted emergence values for the station.

The relationships of index combination to emergence (Fig. 1) and bud development (Fig. 2) indicate a different pattern for the 2 west-most (Ontario) weather stations than in the 4 easterly stations (Quebec and New Brunswick). At Cameron Falls (ON), April values of the combination of Pacific/North American (PNA) pattern and Northern Annular Mode (NAM) climate indices showed the most significant relationship to both emergence and bud flush, while at Cochrane (ON), it is the April Pacific Decadal Oscillation (PDO) and NAM combination that is most significant. In the Quebec and New Brunswick locations, it is May values of the PDO and East Pacific (EP) combination of index values which is most significant. 

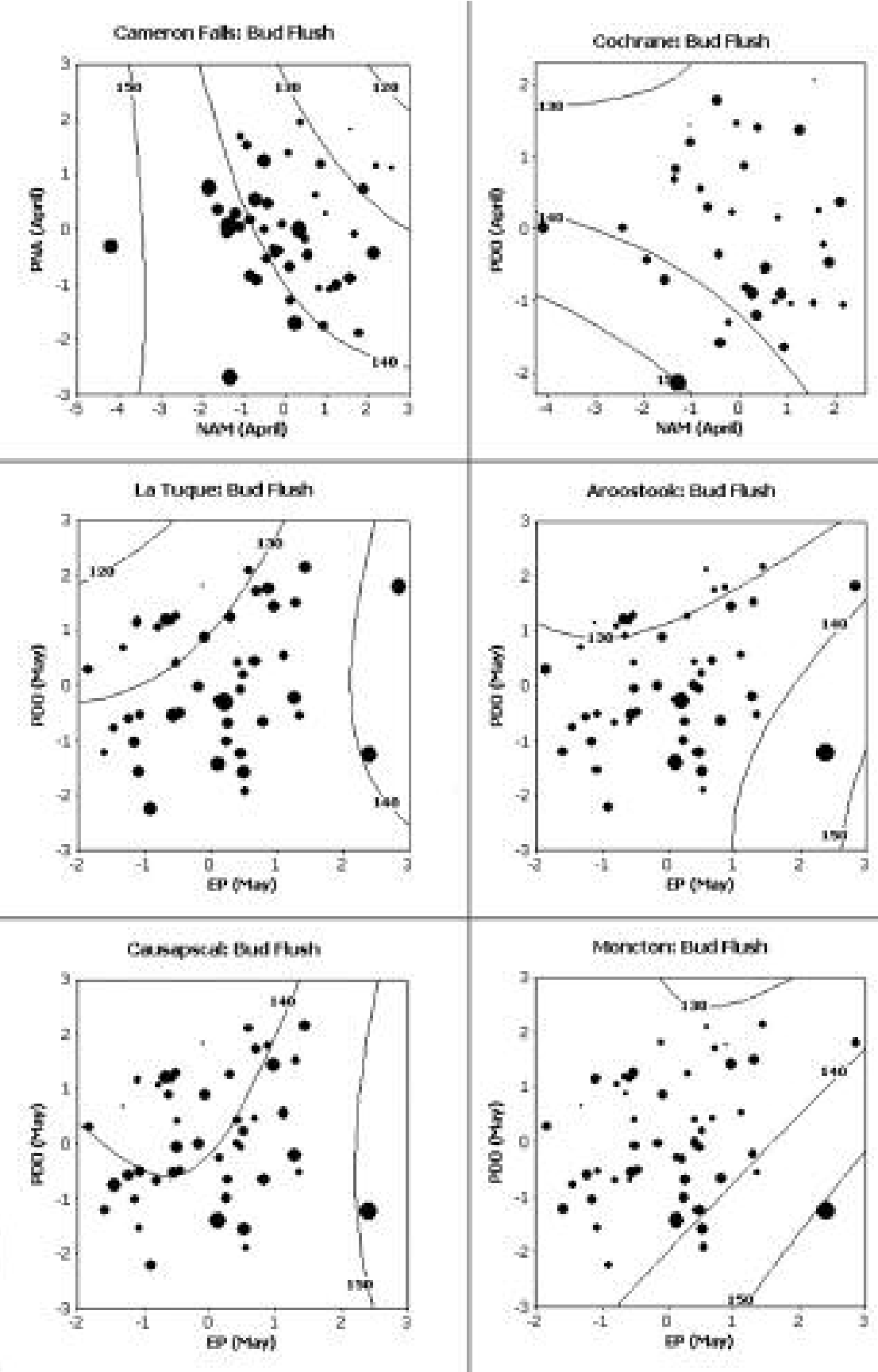

Fig. 2. Relationship of climate indices to timing of balsam fir bud flush for the stations in the study, in order from west to east. $r^{2}$ values are listed in Table 3. Point size is scaled between the smallest at the minimum and maximum predicted bud flush values for the station.

\section{Late frosts}

Variability in timing of late frosts was used to show that while the data of Osawa et al. (1983) were used across the geographical range of stations, actual DD parameters (starting date, total or threshold) in distant locations may be considerably different from those used in this study. Assuming that late frosts are linked to minimum air temperatures below zero, Cochrane is subject to much later frosts than Aroostook (Fig. 3). 
Table 3. Best fit (highest $\mathrm{r}^{2}$ ) of response surfaces of emergence and bud flush fitted to April and May values of pairs of climate indices. Station and index abbreviations are as in Tables 1 and 2 respectively.

\begin{tabular}{llllll}
\hline & \multicolumn{2}{c}{ Emergence } & & \multicolumn{2}{c}{ Bud Flush } \\
\cline { 2 - 3 } \cline { 5 - 6 } Station & Indices & $\mathbf{r}^{2}$ & & Indices & $\mathbf{r}^{2}$ \\
\hline CF & PNA-NAM (April) & 0.41 & & PNA-NAM (April) & 0.40 \\
Coc & PDO-NAM (April) & 0.29 & & PDO-NAM (April) & 0.29 \\
LaT & PDO-EP (May) & 0.26 & & PDO-EP (May) & 0.30 \\
Aro & PDO-EP (May) & 0.23 & & PDO-EP (May) & 0.38 \\
Cau & PDO-EP (May) & 0.32 & & PDO-EP (May) & 0.26 \\
Mon & PDO-EP (May) & 0.30 & & PDO-EP (May) & 0.35 \\
\hline
\end{tabular}

\section{Cochrane and Aroostook}

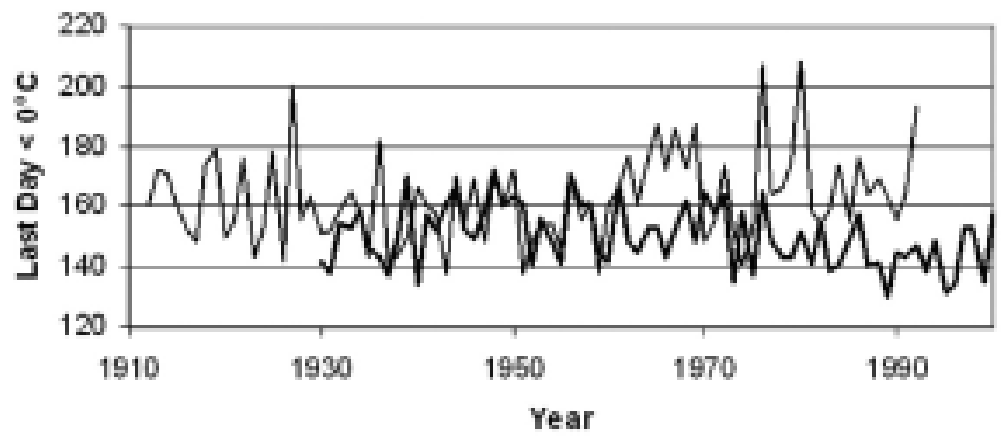

Fig. 3. Last day with minimum temperature less than zero (a surrogate for late frosts) at Cochrane and Aroostook (heavy line).

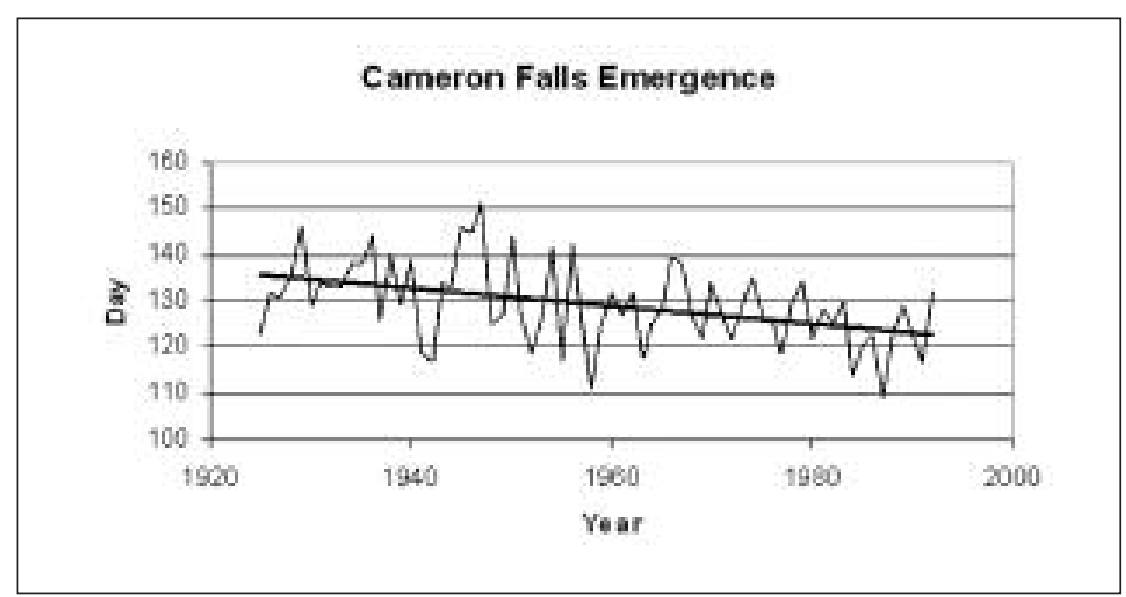

Fig. 4. Change in budworm emergence timing at Cameron Falls in response to a longterm March and April warming trend.

\section{Long-term patterns}

Only the years 1950 to 2000 were included in the study of climate indices. However, weather records are available from earlier years, and in some cases have changed significantly over time. For example, maximum April temperature at Cameron Falls has increased, with a consequent decrease in estimated emergence date (Fig. 4).

\section{Discussion}

Mountain pine beetle-killing temperatures in western Canada have been found to be highly correlated with the combination of the PNA and NAM climate indices, with the pattern of the relationship varying regularly across the geographic range of stations studied. Similarly, in the present study, larval emergence and balsam fir bud flush across eastern Canada are related to the combination of climate indices (Fig. 1, Fig. 2), in particular to the combination of April PDO or PNA with NAM in Ontario, and May PDO with EP in Quebec and New Brunswick. This would suggest that outbreak dynamics might be different in different parts of the range. In Ontario, the last 2 outbreaks were separated by 35 years (Nealis and Régnière 2004), while in New Brunswick, the separation was 22 years

(Fig. 2 of Royama 1984). Note that EP is associated with changes in the jet stream pattern. ${ }^{4}$

Bud flush data from a single location were used with all weather stations in this study. However, the analysis above (Fig. 3) suggests limitation to the appropriateness of the bud flush data in other locations. Bud flush studies across the range of balsam fir would facilitate estimation of synchronization.

The present study focused only on statistical best fit to historical patterns. However, 2 other considerations are significant for pest management: how useful are particular indices for long term forecasting, and how well understood are expected effects of climate change on the indices used (Thomson 2009). Different forecasting approaches exist, but different approaches have been found to be suitable in different parts of North America (Hill et al. 2000), and in any event the relationship of conditions at a specific location to these indices can be highly complex (Moore et al. 2002). Also, as indicated in Fig. 4, the future may be different from the past. The relationship of climate indices to outbreak patterns therefore remains a fruitful area for future research.

\section{References}

Allan, R., J. Lindesay and D. Parker. 1996. El Niño, Southern Oscillation and Climate Variability. CSIRO Publishing, Collingwood, Victoria, Australia.

Blais, J.R. 1985. The ecology of the eastern spruce budworm: a review and discussion. In C.J. Sanders, R.W. Stark, E.J. Mullins and J. Murphy (eds.). Recent advances in spruce budworm research. pp. 49-59. Canadian Forestry Service, Ottawa, ON.

Brolley, J., J.J. O’Brien, J. Schoof and D. Zierden. 2007. Experimental Drought Threat Forecast for Florida. Agric. For. Meteorol. 145: 84-96.

${ }^{4}$ http://www.cpc.noaa.gov/data/teledoc/ep.html.031500 [Accessed April 18, 2005] 
Cameron, D.G., G.A. McDougall and C.W. Bennett. 1968. Relation of spruce budworm development and balsam fir shoot growth to heat units. J. Econ. Entomol. 61: 857-858.

Hallett, T.B., T. Coulson, J.G. Pilkington, T.H. Clutton-Brock, J.M. Pemberton and B. Grenfell. 2004. Why large-scale climate indices seem to predict ecological processes better than local weather. Nature 430: 71-75.

Hill, H.S.J, J. Park, J.W. Mjelde, W. Rosenthal, H.A. Love and S.W. Fuller. 2000. Comparing the value of Southern Oscillation index based climate forecast methods for Canadian and U.S. wheat producers. Agric. For. Meteorol. 100: 261-272.

Hsieh, W.W., B. Tang and E.R. Garnett. 1999. Teleconnections between Pacific sea surface temperatures and Canadian prairie wheat yield. Agric. For. Meteorol. 96: 209-217.

Hurrell, J.W. 1995. Decadal trends in the North Atlantic Oscillation and relationships to regional temperature and precipitation. Science 269: 676-679.

Hurrell, J.W., Y. Kushnir, G. Ottersen and M. Visbeck. 2003. An Overview of the North Atlantic Oscillation. In The North Atlantic Oscillation: Climatic Significance and Environmental Impact. Geophysical Monograph Series, American Geophysical Union 134: 1-36. Jönsson, A.M., S. Harding, L. Bärring and H.P. Ravn. 2007. Impact of climate change on the population dynamics of Ips typographus in southern Sweden. Agric. For. Meteorol. 146: 70-81.

Kemp, W.P., D.G. Burnell, D.O. Everson and A.J. Thomson. 1983. A comparison of methods for estimating missing daily maximum and minimum temperatures. J. Climate and Appl. Meteorol. 22: 1587-1593.

Kitzberger, T., T.W. Swetnam and T.T. Veblen. 2001. Inter-hemispheric synchrony of forest fires and the El Niño-Southern Oscillation. Global Ecology and Biogeography 10: 315-326.

Moore, G.W.K., G. Holdsworth and K. Alverson. 2002. Climate change in the North Pacific region over the past three centuries. Nature 420: 401-403.

Nealis, V.G. and J. Régnière. 2004. Insect-host relationships influencing disturbance by the spruce budworm in a boreal mixedwood forest. Can. J. For. Res. 34: 1870-1882.
Osawa, A., C.A. Shoemaker and J.R. Stedinger. 1983. A Stochastic Model of Balsam Fir Development and Its Use in Spruce Budworm Control. Forest Science 29: 478-490.

Pereira M.G., R.M. Trigo, C.C. DaCamara, J.M.C. Pereira and S.M. Leite. 2005. Synoptic patterns associated with large summer forest fires in Portugal. Agric. For. Meteorol. 129: 11-25.

Royama, T. 1984. Population dynamics of the spruce budworm Choristoneura fumiferana. Ecological Monographs 54: 429-462.

Salinger, M.J., C.J. Stigter and H.P. Das. 2000. Agrometeorological adaptation strategies to increasing climate variability and climate change. Agric. For. Meteorol. 103: 167-184.

Stenseth, N.C. and A. Mysterud. 2005. Weather packages: finding the right scale and composition of climate in ecology Journal of Animal Ecology 74: 1195-1198.

Thomson, A.J. 2009. Climate indices and mountain pine beetlekilling temperatures. For. Chron. 85: 105-109.

Thomson, A.J. and R. Benton. 2007. A 90-year sea warming trend explains outbreak patterns of western spruce budworm on Vancouver Island. For. Chron. 83: 867-869.

Thomson, A. J., R.F. Shepherd, J.W.E. Harris and R.H. Silversides. 1984. Evaluating weather effects on western spruce budworm by analysis of long-term weather records. Can. Ent. 116: 375-381.

van Asch, M. and M.E. Visser. 2007. Phenology of forest caterpillars and their host trees: The importance of synchrony. Ann. Rev. Ent. 52: 37-55.

van Bael, S.A., A. Aiello, A. Valderrama, E. Medianero, M. Samaniego and S.J. Wright. 2004. General herbivore outbreak following an El Niño-related drought in a lowland Panamanian forest. Journal of Tropical Ecology 20: 625-633.

Vidmar, T.J. and J.W. McKean. 1996. A Monte Carlo study of robust and least squares response surface methods. Journal of Statistical Computation and Simulation 54: 1-18.

Zhou, Y., R.W. Higgins and H.-K. Kim. 2001. Relationships between El Niño-Southern Oscillation and the Arctic Oscillation: A Climate-Weather Link. NCEP/Climate Prediction Center ATLAS 8. Available at http://www.cpc.noaa.gov/research_papers/ncep_cpc_ atlas/8/ [Accessed 6 November 2008]. 